\title{
STOMACH WALL CHANGES AFTER GASTROPLICATION IN PATIENTS WITH MORBID OBESITY
}

\author{
Galimov OV, Khanov VO $₫$, Ziangirov RA, Galimova ES, Minigalin DM, Galimov DO
}

Bashkir State Medical University, Ufa, Russia

Morbid obesity is a distinct disorder which leads to metabolic disorders and to the development of many severe chronic diseases, therefore, the effective treatment of the disorder is an urgent problem of modern medicine. Currently, morbid obesity and the corresponding disorders are a growing problem associated with a significant risk of morbidity and mortality. The study was aimed to assess the morphological and functional changes in the stomach wall after gastroplication performed by the new method worked out in the Clinic of the Department of Surgical Diseases and New Technologies of the Bashkir State Medical University. Gastroplication was performed in 15 male rabbits of the Gray Giant breed aged 12-16 months weighting 3050-5380 g. The animals were withdrawn from the experiment 3, 6 and 12 months after surgery, followed by histological examination of the stomach wall plicated section. Changes in the mucous membrane and the muscle layer of the stomach wall after gastroplication were adaptive and associated with no severe morphological impairment. That made it possible to use the method in clinical practice in 15 patients with morbid obesity, 9 women and 6 men aged $42 \pm 2.1$. In most patients (13 people, 86.7\%), a steady decrease in the body weight was achieved during the first 2-12 months. Long-term treatment results had been tracked during two years. It has been confirmed, that the new laparoscopic gastroplication technique does not lead to pathological changes in the stomach wall plicated section, therefore, the simple and cost-effective method may be used in clinical practice for treatment of patients with morbid obesity.

Keywords: bariatric surgery, gastroplication, clinical and experimental studies, operations on rabbits, laparoscopic surgery

Author contribution: Galimov OV, Khanov VO — study concept and design; Khanov VO, Ziangirov RA, Galimova ES — study planning; Minigalin DM, Galimov DO, Galimova ES — literature analysis; Ziangirov RA, Minigalin DM, Galimov DO — data acquisition and processing; Galimova ES, Minigalin DM — statistical analysis; Galimov OV, Khanov VO, Minigalin DM - data interpretation; Minigalin DM, Galimov DO - manuscript preparation; О. В. Галимов, В. О. X Galimov OV, Khanov VO, Ziangirov RA — editing.

Compliance with ethical standards: the clinical study was approved by the Ethics Committee of the Bashkir State Medical University Clinic (protocol № 47 dated May 29,2020$)$. The informed consent was submitted by all patients or their legal representatives. The animals were treated in strict compliance with the Declaration of Helsinki, Directive 2010/63/EU of the European Parliament and the Council (September 22, 2010) on the protection of animals used for scientific purposes, and Good Laboratory Practice guidelines established by the Order 708n of the Ministry of Healthcare of the Russian Federation (August 23, 2010).

$\square$ Correspondence should be addressed: Vladislav O. Khanov Sultanova, 24-24, Ufa, 450076; khanovv@mail.ru

Received: 12.06.2020 Accepted: 26.06.2020 Published online: 13.07.2020

DOI: $10.24075 /$ brsmu.2020.041

\section{ИЗМЕНЕНИЯ В СТЕНКЕ ЖЕЛУДКА ПОСЛЕ ГАСТРОПЛИКАЦИИ У ПАЦИЕНТОВ С МОРБИДНЫМ ОЖИРЕНИЕМ}

\author{
О. В. Галимов, В. О. Ханов $џ$, Р. А. Зиангиров, Е. С. Галимова, Д. М. Минигалин, Д. О. Галимов
}

Башкирский государственный медицинский университет, Уфа, Россия

Морбидное ожирение - самостоятельное заболевание, ведущее к метаболическим нарушениям и развитию многих серьезных хронических заболеваний, поэтому его эффективное лечение является актуальной проблемой современной медицины. На сегодняшний день морбидное ожирение и ассоциированные с ним заболевания представляют собой все возрастающую проблему, связанную со значительным риском заболеваемости и смертности. Целью исследования было изучить морфофункциональные изменения в стенке желудка после выполнения гастропликации в новом варианте, разработанном на базе кафедры хирургических болезней и новых технологий Башкирского государственного медицинского университета. Гастропликацию выполнили 15 кроликам-самцам породы «Серый великан» в возрасте 12-16 месяцев, весившим 3050-5380 г. Животных выводили из эксперимента через 3, 6 и 12 месяцев с последующим гистологическим изучением стенки пликированного участка желудка. Изменения, происходившие в слизистой и мышечном слое стенки желудка после гастропликации, носили адаптивный характер и не сопровождались серьезными морфологическими нарушениями. Это позволило применить способ в клинической практике у 15 пациентов с морбидным ожирением, 9 женщин и 6 мужчин в возрасте $42 \pm 2,1$ лет. В дальнейшем у большинства (13 пациентов, 86,7\%) удалось достичь стойкого снижения массы тела в течение первых 2-12 месяцев. Отдаленные результаты лечения отслеживали в течение двух лет. Было установлено, что разработанная методика лапароскопической гастропликации не вызывает патологических изменений стенки желудка в пликированной ее части, поэтому ее можно применять в клинической практике для лечения пациентов с морбидным ожирением как технически простую и экономически эффективную.

Ключевые слова: бариатрическая хирургия, гастропликация, клинико-экспериментальная работа, операции на кроликах, лапароскопические вмешательства

Вклад авторов: О. В. Галимов, В. О. Ханов - концепция и дизайн исследования; В. О. Ханов, Р. А. Зиангиров, Е. С. Галимова - планирование исследования; Д. М. Минигалин, Д. О. Галимов, Е. С. Галимова - анализ литературы; Р. А. Зиангиров, Д. М. Минигалин, Д. О. Галимов - сбор и обработка данных; Е. С. Галимова, Д. М. Минигалин - статистическая обработка; О. В. Галимов, В. О. Ханов, Д. М. Минигалин - интерпретация данных; Д. М. Минигалин, Д. О. Галимов - подготовка рукописи; О. В. Галимов, В. О. Ханов, Р. А. Зиангиров - редактирование.

Соблюдение этических стандартов: клиническая работа одобрена этическим комитетом Клиники ФГБОУ ВО БГМУ Минздрава России (протокол № 47 от 29 мая 2020 г.). Добровольное информированное согласие получено от всех участников исследования или их законных представителей. Условия содержания животных и работы с ними соответствовали принципам Хельсинской декларации о гуманном отношении к животным, директиве Европейского парламента и Совета Европейского союза 2010/63/ЕС от 22 сентября 2010 г. о защите животных, используемых для научных целей, «Правилам лабораторной практики в Российской Федерации", утвержденным приказом Министерства здравоохранения РФ № 708 н от 23 августа 2010 г.

$\square$ Для корреспонденции: Владислав Олегович Ханов ул. Султанова, д. 24, кв. 24, г. Уфа, 450076; khanovv@mail.ru

Статья получена: 12.06.2020 Статья принята к печати: 26.06.2020 Опубликована онлайн: 13.07.2020

DOI: $10.24075 /$ vrgmu.2020.041 
In recent years, in all countries in the doctors of various specialties, there is a growing interest to the problem of metabolic disorders. According to some sources, about 250 million people are obese, representing approximately $7 \%$ of the world's adult population. According to $\mathrm{WHO}$, in the developed world, about one third (33.3\%) of the population has excess body weight $[1,2]$. The consequences of the metabolic syndrome as a complication of obesity are a significant reduction in life expectancy and a decrease in the quality of life. Meanwhile, the risk of severe metabolic disorders, such as type 2 diabetes mellitus, hypertension, coronary heart disease, increases significantly, which leads to an increase in mortality of patients aged under 40 by 12 times. Most modern researchers recognize that that conservative treatment of extreme obesity is an extremely difficult and for $90-95 \%$ of patients impossible task [3-5].

Most authors substantiate the need to use a powerful resource of various surgical methods for correction of associated with obesity pathological changes by the rapid increase in the number of obese patients and a significant increase in the cost of their treatment $[6,7]$. The use of surgical methods for treating patients with metabolic syndrome is the most effective way to combat morbid obesity, especially in patients with complications. This requires a special approach, both in the pre-operative preparation and in the intra- and postoperative management, which is due to concomitant pathologies of vital organs and systems detected in all patients [8-10].

In bariatric surgery, there is a well known procedure for reducing gastric volume via invagination of the stomach wall section in the lumen (suturing a fold using the corrugated seromuscular sutures) along the greater curvature [11, 12]. A group of authors has reported the 12-year experience of laparoscopic gastroplication performed in the Laleh and Sina hospitals (Iran) in more than 800 patients $[13,14]$. However, currently there are no literature data on the morphological changes in the stomach wall after gastroplication, and therefore the importance of the research is unquestionable [15].

In the Clinic of the Department of Surgical Diseases and New Technologies of the Bashkir State Medical University, the surgical treatment of morbid obesity and metabolic syndrome has been carried out since 2003. For a long period, many generally accepted methods have been used, and the new original methods have been developed. The various invasive bariatric procedures were performed in 165 patients with their body mass index (BMI) exceeding $35 \mathrm{~kg} / \mathrm{m}^{2}$. In recent years, the restrictive surgery has been preferred, especially the sleeve gastrectomy performed mainly by laparoscopy.

An alternative to sleeve gastrectomy, aimed at reducing the stomach volume, is the gastric placation procedure (gastroplication). We have introduced a new method of laparoscopic gastroplication for the surgical treatment of patients with morbid obesity. The method consists of gastric volume reducing due to intraluminal folding (invagination) of the stomach wall section with the help of the specific surgical instrument (suturing a fold using the corrugated sero-muscular sutures) along the greater curvature (Fig. 1). The stomach volume is significantly reduced, and the patient starts feeling full when eating significantly faster than prior to surgery. The technical result is achieved via mobilization of the stomach wall along the greater curvature using the specially designed instrument (intestinal forceps), folding the stomach wall into the tube in the form of a "roll", and fixation with a non-absorbable filament. The reduction of gastric volume up to $50 \mathrm{ml}$ is achieved using the special calibration tube [16].

Some authors, noting the obvious advantages of gastroplication in the treatment of obesity (simple, costeffective), draw attention to risks and uncertainties associated with the morphological and physiological state of the gastric wall in the plicated section [7, 12].

The study was aimed to assess the morphological and functional changes in the stomach wall after gastroplication performed by the new method developed in the Clinic of the Department of Surgical Diseases and New Technologies of the Bashkir State Medical University.

\section{METHODS}

To assess the histopathological features changes in the invaginated stomach section and to detect the changes capable of causing complications in the postoperative period, the clinical and experimental study was carried out in the veterinary clinic of the Bashkir State Agrarian University in 2017-2020, consisting of performing surgery in 15 rabbits [10]. All rabbits were males of the Gray Giant breed aged 12-16 months. The rabbits' weight varied between 3050-5380 g. Inclusion criteria: age 12-16 months, male, weight $3 \mathrm{~kg}$ or above. Exclusion criteria: any disease, history of abdominal surgery, weight below $3 \mathrm{~kg}$, female, participation in any other experiment.

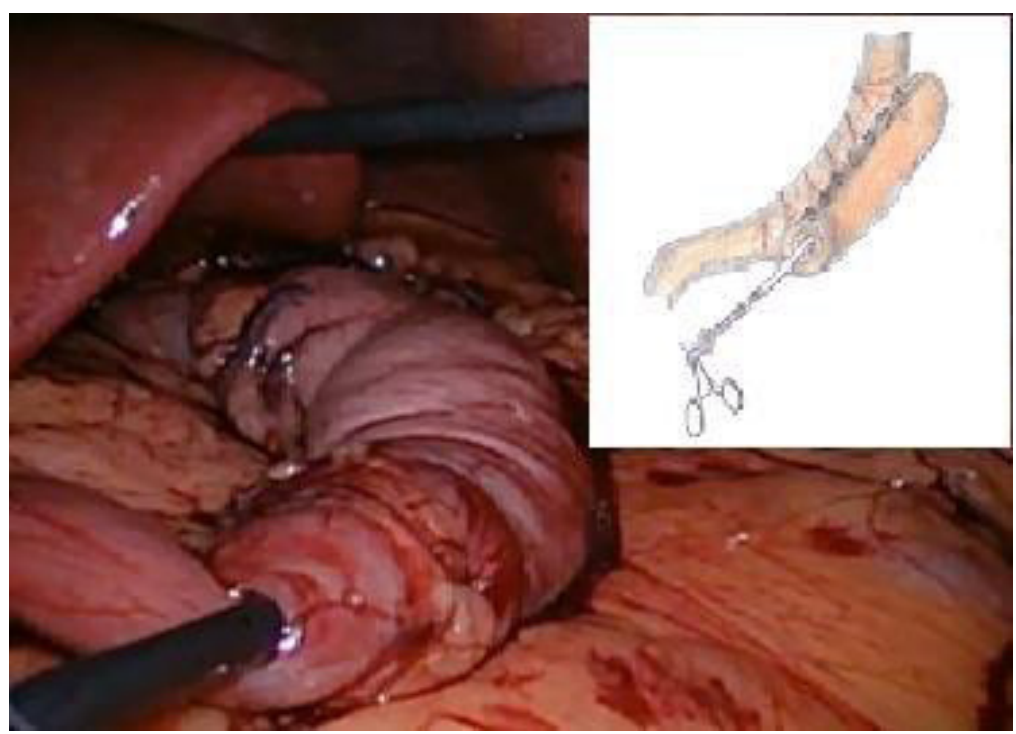

Fig. 1. Gastroplication through folding of the stomach, the new surgical precedure 
Two days before surgery, the rabbits were moved to separate cages. The animals received water only for the gastric contents evacuation. All the rabbits underwent gastroplication. The timing of operation was 12-19 min (the average value was $14.5 \mathrm{~min})$. After the three-time preoperative cleansing of the operative field with chlorhexidine alcohol-based solution the upper midline laparotomy was performed under the combined anesthesia (tiletamine-zolazepam-xylazine hydrochloride). The stomach was visualized sized $5.0 \times 9.0 \mathrm{~cm}$. It was mobilized along the greater curvature. Then the stomach was fixed in the margin opposite to mesenteric by the intestinal forceps, folded in the "roll"; suturing with sero-muscular sutures, layered closure of the wound.

During the postoperative period, the rabbits were monitored in separate cages, on the day 3 after surgery the animals received grain, on the day 5-6 they received hay and grass. The animals were administered with the solutions of $5 \%$ glucose, $0.9 \%$ saline in a volume of $20 \mathrm{ml}$ intramuscularly, together with $0.5 \mathrm{ml}$ of B12 vitamin, $0.1 \mathrm{~g}$ of biomycin twice a day.

Three and 6 months after surgery, with the appropriate preparation and in similar conditions, a second surgical procedure was performed, the resection of the stomach plicated section. The resected specimen was placed in the 10\% formalin for further histological examination. The specimens were also taken 6-12 months after gastroplication.

For histological examination, a piece of tissue sized $1 \times 1 \mathrm{~cm}$, containing all layers of the stomach wall, was taken from the plicated section (from the various stomach regions). The biopsied material was fixed in the 10\% formalin, and after the histological wiring, serial sections with a thickness of $7 \mu \mathrm{m}$ were obtained. The sections were stained with hematoxylin and eosin.

In the clinical practice, the described method was used in 15 patients with morbid obesity and metabolic syndrome. The sample included patients aged over 18 with BMI $35-45 \mathrm{~kg} / \mathrm{m}^{2}$. There were 9 women and 6 men aged $42 \pm 2.1$. The patient selection criteria were stringent, gastroplication was chosen for motivated patients able to continuously follow diet control and exercise after surgery.

Inclusion criteria: high BMl (> $35 \mathrm{~kg} / \mathrm{m}^{2}$ ) with comorbidities, age over 18. A number of exclusion criteria were chosen for patients in order to improve homogeneity of the operated patients group. Exclusion criteria: acute exacerbation or decompensation of chronic disorder, history of myocardial infarction or cerebrovascular accident, age under 18, psychological or mental disorders, no weight loss trigger.

Statistical analysis was carried out by standard methods using the Microsoft Excel application (Microsoft; USA).

\section{RESULTS}

In the early postoperative period three rabbits had complications: dyspepsia (refused food and water) and apathy. During the further follow-up, on the day 3-4 the animals started drinking water. Then they had slowly begun to eat solid food. No rabbits died during the experiment.

When examining the material taken 3 months after surgery, the macroscopic investigation revealed no obvious pathological changes. Slight cicatricial and sclerotic changes in the folded stomach section were noted, which did not obstruct unfolding the plicated section when removing the sutural material. Microscopic examination of sections and comparison with the unchanged stomach section (Fig. 2) revealed slight dystrophic changes of the gastric superficial-foveolar epithelium (singlelayered prismatic glandular epithelium) in the plicated section of the stomach. Small gastric pits, rims evenly smoothed; slightly atrophic glands; mild glands epithelium dystrophy; moderate interstitial edema in the stroma; small mild sclerosis foci; low focal lymphoid infiltration; vessels with uneven blood filling, sclerotic changes in some vessel walls; some erythrocytes in the vessel lumens; edema and focal perivascular hemorrhages in the submucosa and muscle layer; fragments of sutural material found in single sections; serous membrane thickened due to uneven sclerotic changes and low focal lymphoid infiltration (Fig. 3).

When examining specimens taken 6 months after surgery, the macroscopic investigation revealed pronounced cicatricial changes, it was impossible to unfold the invaginated part of the stomach without damaging or dissecting the tissues. Microscopic examination of sections and comparison with the section which had been obtained 3 months before revealed pronounced distrophic changes of the superficial-foveolar epithelium in the plicated stomach section. Gastric pits and rims evenly smoothed; moderate gland atrophy; moderate gland epithelium dystrophy; decreased interstitial edema of stroma; sclerosis foci dissemination in the mucosa subepithelial sections and vessel walls; low focal lymphoid infiltration; some erythrocytes in the vessel lumens; decreased edema in the submucosa and muscle layer, uneven sclerotic foci; no

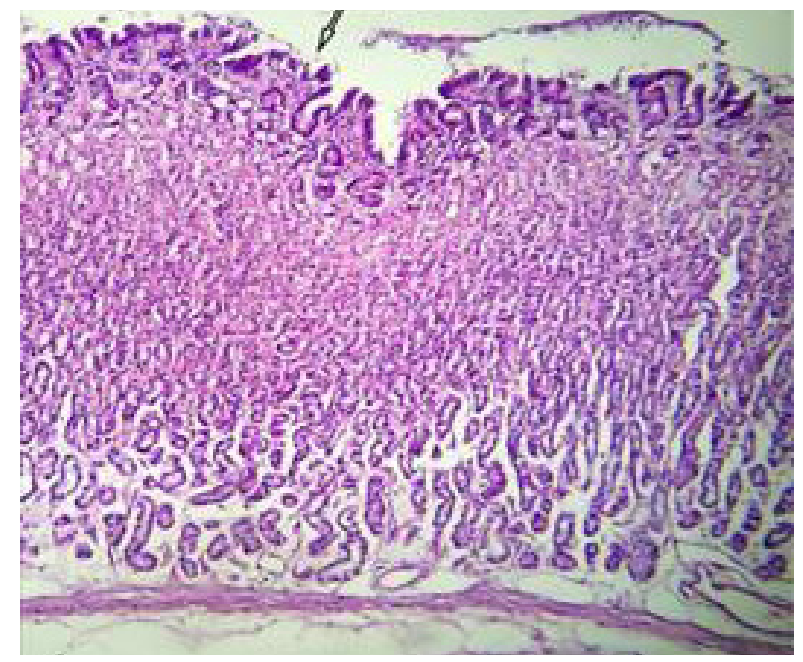

Fig. 2. Unchanged gastric mucosa (hematoxylin and eosin stain, magnification $40 x-64 x)$

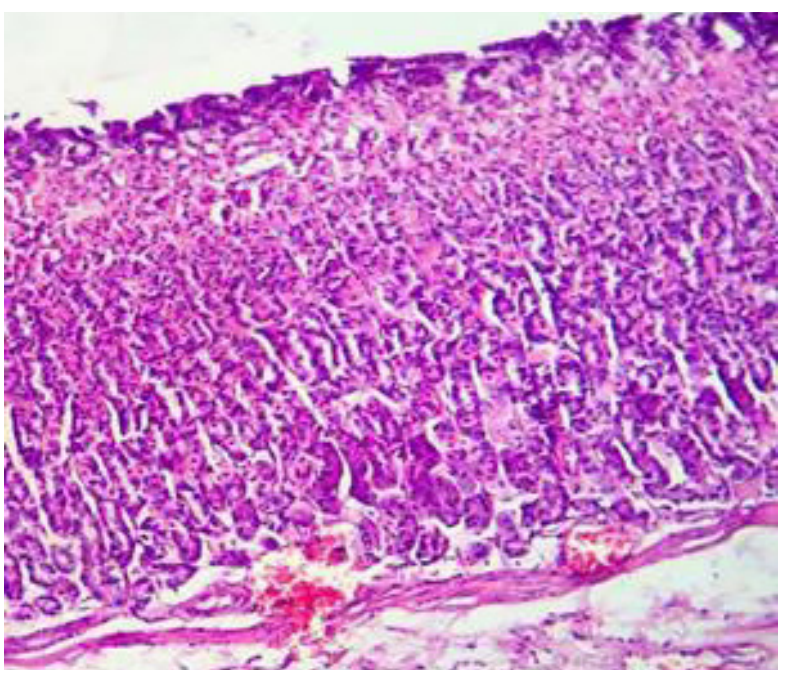

Fig. 3. Gastric mucosa from the plicated section obtained 3 months after surgery (hematoxylin and eosin stain, magnification 40x-64x). Dystrophic changes of the gastric superficial-foveolar epithelium (single-layered prismatic glandular epithelium) 
fragments of sutural material; serous membrane thickened due to proliferating fibrous connective tissue (Fig. 4).

The first results of surgical procedures performed at the Clinic by the proposed method demonstrated that in the early postoperative period no complications were observed in the studied group of patients. Later in most patients (13 people, $86.7 \%$ ) a steady decrease in the body weight was achieved during the first 2-12 months. It should be noted that two patients (13.3\%) failed to achieve a consistent result. After the 3 months weight loss, the negative dynamics were noted, patients began to gain weight again. The long-term results were tracked in five patients (33.3\%) for 24 months. In two patients, the weight loss and its stabilization at acceptable level occurred. In three patients, the weight loss was followed by weight gain subject to correction by therapeutic methods. Upon the followup appointment, the patients underwent additional instrumental examinations aimed to control the formed gastric tube condition (fibrogastroduodenoscopy, contrast radiography, and computed tomography, if necessary). No abnormalities in the operated stomach region or complications associated with the digestive system functioning were noted.

\section{DISCUSSION}

According to some authors $[13,14]$, laparoscopic gastroplication is no less effective than other restrictive methods aimed at weight loss. Moreover, the discussed method has a number of advantages: it is significantly cheaper, less complications (0.6\%), over the past 12 years only $31 \%$ of cases with repeated weight gain have been recorded, simple rehabilitation. The method may be reversible, if necessary. It also makes it possible to use the additional malabsorptive procedures (second-step surgery) in patients with insufficient weight loss [14]. However, currently there are no published data on morphological changes in the gastric wall after gastroplication. The study demonstrated that the changes found in the mucous membrane and the muscle layer of the stomach wall after gastroplication were adaptive and associated with no severe morphological impairment.

When choosing the type of surgical procedure, it should be considered that patients need a potential trigger for weight loss, such as gastroplication. Our observations demonstrate that gastroplication is effective in preserving the diet during several years. In the postoperative period, within one year, eight operated patients (53.3\%) were subjected to comprehensive examination including fibrogastroduodenoscopy, contrast radiography of stomach and duodenum, abdominal computed tomography. According to the examination results, the plicated stomach had volume less than prior to surgery. No food passage and digestion impairment or associated with surgery abdominal cavity organs pathological changes were observed.

Small sample size and short observation period make it impossible to report the significant treatment results. However, the study is of practical interest due to the low cost and technical simplicity of one of the acknowledged surgical intervention types used in metabolic surgery in patients with morbid obesity.

\section{CONCLUSIONS}

In patients with morbid obesity, the weight loss is achieved due to bariatric surgery. Experimental study results demonstrate that the stomach wall changes after gastroplication are adaptive and associated with no severe morphological impairment. The study of the discussed method usage clinical evidence allows us to consider the method quite effective, simple, and enabling to improve the outcome of treatment in patients with overweight and obesity.

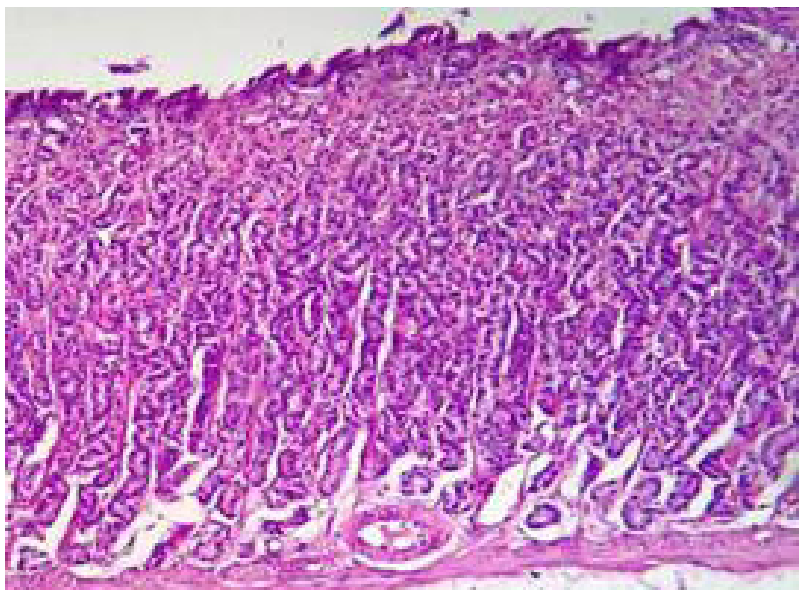

Fig. 4. Gastric mucosa from the plicated section obtained 6 months after surger (hematoxylin and eosin stain, magnification 40x-64x). Pronounced dystrophic changes of the superficial-foveolar epithelium, gastric pits and rims evenly smoothed; moderate gland atrophy

\section{References}

1. Fried M, Yumuk V, Oppert JM, et al. Interdisciplinary European guidelines on metabolic and bariatric surgery. Obes Surg. 2014; 24 (1): 42-55. DOI: 10.1007/s11695-013-1079-8.

2. Borz C, Bara TJ, Bara T, et al. Laparoscopic gastric plication for the treatment of morbid obesity by using real-time imaging of the stomach pouch. Ann Ital Chir. 2017; 6: 392-8. PMID: 29197192.

3. Fedenko V, Evdoshenko VV, Kurganov IA, Emeljanov SI, Matveev NL, Bogdanov DJu, Mazikina LN. Sravnitel'nyj analiz jeffektivnosti laparoskopicheskoj rukavnoj rezekcii zheludka i laparoskopicheskogo zheludochnogo shuntirovanija u bol'nyh s saharnym diabetom 2-go tipa i narusheniem tolerantnosti $k$ gljukoze. Jendoskopicheskaja hirurgija. 2016; 2: 21-31. Russian.

4. Jashkov Jul, Lucevich OJe, Bordan NS, Ivleva OV. Jeffektivnost laparoskopicheskoj prodol'noj rezekcii zheludka u bol'nyh ozhireniem. Ozhirenie i metabolizm. 2015; 12 (1): 20-8. Russian.

5. Zerrweck C, Rodríguez JG, Aramburo E, et al. Revisional surgery following laparoscopic gastric plication. Obes Surg. 2017; 27 (1):
38-43. DOI: 10.1007/s11695-016-2242-9.

6. Anishhenko W, Semenov SA, Halzov AV. Vybor metoda operacii pri ozhirenii. Al'manah Instituta hirurgii im. A.V. Vishnevskogo. 2012; 7 (1): 130-1. Russian.

7. Brethauer SA, Harris JL, Kroh M, Schauer PR: Laparoscopic gastric plication for treatment of severe obesity. Surg Obes Relat Dis. 2011; 7: 15-22.

8. Galimov OV, Hanov VO, Gabdulsabirova ZR. Rezul'taty hirurgicheskih operacii i kachestva zhizni pacientov posle razlichnyh variantov bariartricheskih vmeshatel'stv. Kreativnaja hirurgija i onkologija. 2011; 1: 39-44. Russian.

9. Pujol Gebelli J, Garcia Ruiz de Gordejuela A, Casajoana Badia A, Secanella Medayo L, Vicens Morton A, Masdevall Noguera C. Laparoscopic Gastric Plication: a new surgery for the treatment of morbid obesity. Cir Esp. 2011; 89 (6): 356-61.

10. Skovorodin EN, Vehnovskaja EG. Rukovodstvo k laboratornym zanjatijam po patologicheskoj anatomii zhivotnyh. Ufa: Bashkirskij gosudarstvennyj agrarnyj universitet, 2015 (3-e izdanie, 
pererabotannoe i dopolnennoe); $258 \mathrm{pp}$. Russian.

11. Askerhanov RG, Hatkov IE, Bodunova NA, Fejdorov IJu, Petrova AL, Sadyki MN. Pervyj opyt laparoskopicheskoj gastroplikacii u pacientov s morbidnym ozhireniem. Jendoskopicheskaja hirurgija. 2017; 1: 6-9. Russian

12. Perivoliotis K, Sioka E, Katsogridaki G, Zacharoulis D. Laparoscopic gastric plication versus laparoscopic sleeve gastrectomy: an upto-date systematic review and meta-analysis. J Obes. 2018; 9: 3617458. DOI: 10.1155/2018/3617458.

13. Heidari R, Talebpour M, Soleyman-Jahi S, Zeinoddini A, Sanjari Moghaddam A, Talebpour A. Outcomes of reoperation after laparoscopic gastric plication failure. Obes Surg. 2019; 29 (2):

\section{Литература}

1. Fried M, Yumuk V, Oppert JM, et al. Interdisciplinary European guidelines on metabolic and bariatric surgery. Obes Surg. 2014; 24 (1): 42-55. DOI: 10.1007/s11695-013-1079-8.

2. Borz C, Bara TJ, Bara T, et al. Laparoscopic gastric plication for the treatment of morbid obesity by using real-time imaging of the stomach pouch. Ann Ital Chir. 2017; 6: 392-8. PMID: 29197192.

3. Феденко В. В., Евдошенко В. В., Курганов И. А., Емельянов С. И., Матвеев Н. Л., Богданов Д. Ю., Мазикина Л. Н. Сравнительный анализ эффективности лапароскопической рукавной резекции желудка и лапароскопического желудочного шунтирования у больных с сахарным диабетом 2-го типа и нарушением толерантности к глюкозе. Эндоскопическая хирургия. 2016; 2: 21-31.

4. Яшков Ю. И., Луцевич О. Э., Бордан Н. С., Ивлева О. В. Эффективность лапароскопической продольной резекции желудка у больных ожирением. Ожирение и метаболизм. 2015; 12 (1): 20-8.

5. Zerrweck C, Rodríguez JG, Aramburo E, et al. Revisional surgery following laparoscopic gastric plication. Obes Surg. 2017; 27 (1): 38-43. DOI: 10.1007/s11695-016-2242-9.

6. Анищенко В. В., Семенов С. А., Хальзов А. В. Выбор метода операции при ожирении. Альманах Института хирургии им. А. В. Вишневского. 2012; 7 (1): 130-1.

7. Brethauer SA, Harris JL, Kroh M, Schauer PR: Laparoscopic gastric plication for treatment of severe obesity. Surg Obes Relat Dis. 2011; 7: 15-22.

8. Галимов О. В., Ханов В. О., Габдулсабирова З. Р. Результаты хирургических операций и качества жизни пациентов после различных вариантов бариартрических вмешательств. Креативная хирургия и онкология. 2011; 1: 39-44.
376-86. DOI: 10.1007/s11695-018-3522-3.

14. Talebpour, et al. Twelve year experience of laparoscopic gastric plication in morbid obesity: development of the technique and patient outcomes. Annals of Surgical Innovation and Research. 2012; 6: 7. Available from: http://www.asir-journal.com/content/6/1/7.

15. Khidir N, Al Dhaheri M, El Ansari W, Al Kuwari M, Sargsyan D, Bashah M. Outcomes of laparoscopic gastric greater curvature plication in morbidly obese patients. J Obes. 2017; 2017: 7989714. DOI: 10.1155/2017/7989714.

16. Galimov OV, Hanov VO, Sagitdinov RR, Sajfullin RR, et al. Method of surgical treatment of overweight and obesity. Russian Federation patent № RU 2654572 C1. 21.05.2018.

9. Pujol Gebelli J, Garcia Ruiz de Gordejuela A, Casajoana Badia A, Secanella Medayo L, Vicens Morton A, Masdevall Noguera C. Laparoscopic Gastric Plication: a new surgery for the treatment of morbid obesity. Cir Esp. 2011; 89 (6): 356-61.

10. Сковородин Е. Н., Вехновская Е. Г. Руководство к лабораторным занятиям по патологической анатомии животных. Уфа: Башкирский государственный аграрный университет, 2015 (3-е издание, переработанное и дополненное); 258 с.

11. Аскерханов Р. Г., Хатьков И. Е., Бодунова Н. А., Фейдоров И. Ю., Петрова А. Л., Садыки М. Н. Первый опыт лапароскопической гастропликации у пациентов с морбидным ожирением. Эндоскопическая хирургия. 2017; 1: 6-9.

12. Perivoliotis K, Sioka E, Katsogridaki G, Zacharoulis D. Laparoscopic gastric plication versus laparoscopic sleeve gastrectomy: an upto-date systematic review and meta-analysis. J Obes. 2018; 9: 3617458. DOI: 10.1155/2018/3617458.

13. Heidari R, Talebpour M, Soleyman-Jahi S, Zeinoddini A, Sanjari Moghaddam A, Talebpour A. Outcomes of reoperation after laparoscopic gastric plication failure. Obes Surg. 2019; 29 (2): 376-86. DOI: 10.1007/s11695-018-3522-3.

14. Talebpour, et al. Twelve year experience of laparoscopic gastric plication in morbid obesity: development of the technique and patient outcomes. Annals of Surgical Innovation and Research. 2012; 6: 7. Available from: http://www.asir-journal.com/content/6/1/7.

15. Khidir N, Al Dhaheri M, El Ansari W, Al Kuwari M, Sargsyan D, Bashah M. Outcomes of laparoscopic gastric greater curvature plication in morbidly obese patients. J Obes. 2017; 2017: 7989714. DOI: 10.1155/2017/7989714.

16. Галимов О. В., Ханов В. О., Сагитдинов Р. Р., Сайфуллин Р. Р. и др. Способ хирургического лечения избыточной массы тела и ожирения. Патент РФ № RU 2654572 C1. 21.05.2018. 